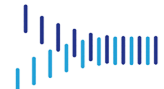 \\ PHPMA}

Published by

Department of Public Health and Preventive

Medicine, Faculty of Medicine,

Udayana University

\section{Evaluation of hypertension screening guidelines implementation at the public health centers in Tabanan District, Bali, Indonesia}

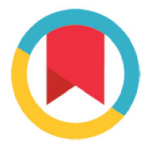

CrossMark

\author{
Gede Agung Ratnata, ${ }^{1 *}$ Dyah Pradnyaparamita Duarsa, ${ }^{2}$ Luh Seri Ani ${ }^{2}$
}

${ }^{1}$ Tabanan District Health Office ${ }^{2}$ Department of Public Health and Preventive Medicine, Faculty of Medicine, Udayana University
*Correspondence to:

Gede Agung Ratnata; Tabanan District Health Office;

agungratnata23@gmail.com

\section{ABSTRACT}

Background and purpose: World Health Organization (WHO) reported the number of people with hypertension worldwide reached one billion in 2015. Hypertension screening is an effort to manage and control hypertension through hypertension management stages. This study aims to explore in-depth the implementation of hypertension screening guidelines performed by the public health centers (PHCs)

Methods: This is a qualitative exploration with an exploratory case study approach by adopting the Lawrence W. Green Theory. This study was conducted in two PHCs in Tabanan District, those with the highest and the lowest target achievement. The factors examined were the implementation of guidelines and factors affecting it. The data were collected using in-depth interviews with ten informants and data were analyzed using thematic methods.

Results: We found the predisposing factors of the implementation including the management of Health Operational Assistance ( $\mathrm{HOA}$ ) funds, the grouping of targets at risk of hypertension, hypertension screening guidelines, and the attitudes and beliefs of the officers and the community. The driving factors consisted of the lack of community participation. The inhibiting factors were indicated by the insufficient number of health workers and community support.

Conclusion: There are several obstacles for the implementation of hypertension screening guidelines both from the health services side including budget allocation and community participation. Therefore, more thorough planning and measures to improve participation is needed.

Keywords: guidelines, hypertension, screening, evaluation, public health center

Cite This Article: Ratnata, G.A., Duarsa, D.P., Ani, L.S. 2021. Evaluation of hypertension screening guidelines implementation at the public health centers in Tabanan District, Bali, Indonesia. Public Health and Preventive Medicine Archive 9(2): 91-99. D0I: 10.15562/phpma.v9i2.323

\section{INTRODUCTION}

Hypertension is one of the noncommunicable diseases (NCDs) marked by an increase in systolic blood pressure $(\geq 140 \mathrm{mmHg}$ ) and/or diastolic blood pressure $(\geq 90 \mathrm{mmHg})$. Hypertension causes an increased risk of heart enlargement, heart attack, and stroke, resulting in increased morbidity and mortality. ${ }^{1}$ Hypertension also causes about $70 \%$ of patients to die from coronary heart disease, $15 \%$ have brain damage, and $10 \%$ have heart failure. ${ }^{2}$

Based on the Basic Health Research (Riset Kesehatan Dasar/Riskesdas) data in 2018, the prevalence of hypertension in Indonesia reached $34.1 \%$ among the adult population aged $\geq 18$ years, the prevalence of people diagnosed with hypertension by health workers reached $8.4 \%$, and the prevalence of people taking medication was $8.8 \%{ }^{1}$ Based on the data obtained from the Bali Provincial Health Office in 2016, Tabanan was a district in Bali Province with the $2^{\text {nd }}$ highest hypertension prevalence at $20.3 \%$, accounted for 11,178 cases. $^{3}$

Hypertension screening is an effort to manage and control hypertension through a series of hypertension management stages, starting from promotive, preventive, curative, and rehabilitative efforts. ${ }^{4}$ To perform a systematic and proper hypertension screening activities, guidelines or technical instructions compiled by cross-program experts at the Ministry of Health and Higher Education, are needed. The Hypertension Screening Guideline is becoming a reference for health workers and program managers in performing each stage of the activities and achieving improvement in hypertension control. The implementation of this guideline also aims to improve the quality of community-based health services, which are performed from the initial stage to the final stage of screening activity, hypertension management and treatment, and also education provision to the community. ${ }^{4}$

In Tabanan District, the 2017 data from Integrated Development Post (posbindu) at 20 public health centers (PHCs) or pusat kesehatan masyarakat (puskesmas) showed 6,616 people $(5.87 \%)$ had hypertension. This number increased to 10,563 people (10.81\%) in 2018. Regarding the target achievement of hypertension cases detection in 2019, of the 20 PHCs in 
Tabanan, Puskesmas Baturiti I achieved the highest target at $41.6 \%$, while Puskesmas Kediri I attained the lowest at only $0.35 \%$.

Based on the Lawrence Green Theory, factors affecting health behavior are grouped into predisposing factors such as individual characteristics and awareness; driving factors such as access to health services; and enforcing factors including support from the environment. Many factors affected the success of hypertension screening activities, the predisposing factors included health workers' knowledge regarding hypertension screening guidelines, which consisted of the flow of screening activities, the health workers involved in each activity, screening management, and recording and reporting process. People's knowledge, attitudes, and beliefs to hypertension were also included in the predisposing factors. The driving factors including the availability of health care facilities and affordability of resources. The enforcing factors included the role of health workers, facilities, infrastructure, and relevant policy including coverage policies. These three factors were interrelated, and they greatly affected the quality of the implementation of hypertension screening activities. ${ }^{5}$

A previous study showed that one of the obstacles for hypertension screening was the low community attendance and interest in participating in screening activities, such as posbindu's activities. ${ }^{6}$ Another study showed the important factor in measuring the success of the hypertension screening implementation was the readiness of the community itself to conduct and utilize the service. ${ }^{7}$ In addition, low awareness on the principles of hypertension control, facilities and infrastructure, and the health workers involved in the screening implementation were indicators to be considered in assessing the quality and success of screening activities. ${ }^{7}$ Meanwhile, another study indicated that the high success rate of screening activities was due to the social factor i.e., family support. ${ }^{8}$

We found limited literatures exploring the implementation of hypertension screening guidelines and factors contributed to the effective implementation. Therefore, this study aims to explore the implementation of hypertension screening guidelines at the PHC level in Tabanan District and factors affecting the implementation.

\section{METHODS}

This is qualitative research with an exploratory case study approach. With this approach, we portray complex phenomena based on exploration of informants' perspectives, supporting data on certain situations and cases. ${ }^{9}$

This study was conducted in the working area of the Tabanan District Health Office. The study location was selected based on data on the target achievement for hypertension detection in all PHCs in Tabanan, where Puskesmas Baturiti I has the highest target achievement while Puskesmas Kediri I has the lowest, these two PHCs were then selected.

The study was conducted from May to June 2020. The data were collected using in-depth interviews with ten informants (i.e., five people in each selected puskesmas), which consisted heads of PHC (2 persons), prevention and control of non-communicable disease program officers (2 persons), health workers (2 persons), health cadres (2 persons), and local people ( 2 persons). The informants were selected by following the adequacy and suitability principles. The sampling technique used was purposive sampling, with several criteria including being aware of the hypertension guideline implementation, involved directly in the hypertension control program, and being beneficiary of the hypertension control programs. $^{10}$

The main instrument in this study was one of the researchers in this study. The researcher was male, 27 years, and working as a Tabanan District Health Office staff with an educational background of Bachelor of Science in Nursing (BSN) and Professional Nurse Program (Registered Nurse/RN). The researcher has an adequate understanding to the topics but with relatively limited experience in conducting qualitative study.

The data collection was conducted by in-depth interview with all informants, interview guideline used to ensure relevant aspects of the study was explored. Several steps were taken in maintaining the data quality in this study, including selection of respondents who were considered to master and understand the problems related to the topic and appropriate time and condition of the interview. Respondents provided informed consent prior to the interview and the interview was then recorded, while the researcher also took important notes. The interview lasted for on average of 30-60 minutes. Then, the transcripts from recordings and interview notes were made immediately after the interviews were completed. This study used thematic analysis as described by Moleong, including these steps: compiling transcripts of the indepth interview results, coding, making categories, and performing analysis based on the research themes. ${ }^{11}$

This study has obtained ethical approval from the Ethics Committee of the Faculty of Medicine, Udayana University, number: 1378/UN 14.2.2.V11.14lLf 12020, dated July 1, 2020.

\section{RESULTS AND DISCUSSION}

\section{Characteristics of Informants}

The informants' characteristics included age, sex, occupation, latest education, position, and length of employment (Table 1). Nine of the ten informants were female including all the head of PHCs, program officers and community cadres, the only male informant was the representative of program beneficiary. The age range of informants was 27-51 years old, with education background varied based on their role. For the PHC staffs, the length of employment ranged from 3-10 years.

\section{Predisposing Factors in the Implementation of Hypertension Screening Guidelines}

Predisposing factors in the implementation of the hypertension screening guidelines were the ones occurring before the activity conducted. Several themes regarding predisposing factors were found during in-depth interviews, which included the knowledge about the implementation of guidelines from the program executors at the PHCs, the availability of funds for the activity, the activity planning process, and the attitudes and beliefs of the community members as the main beneficiaries of this activity. 
Knowledge about the implementation of hypertension screening guidelines The informants described the implementation of the hypertension screening guidelines as all hypertension screening activities adjusted to the screening guidelines and focused on budgeting from the HOA fund. Based on the informants' experience, the screening focused more on grouping the targets at risk. Screening activities had to be performed based on hypertension screening guidelines, and one of the initial planning activities was the budgeting of the HOA fund.

"... We carry out hypertension screening activities at this puskesmas based on the guidelines provided by the Ministry of Health (MoH). So, there are activities related to NCDs conducted at this puskesmas with technical instructions are based on the guidelines from the Ministry of Health since 2010." (R00PK1)

“... We also focused on planning the HOA funds. Besides that, the National Health Insurance Program (NHIP) is also included in the Chronic Disease Management Program (CDMP). Therefore, there will be a budgeting process that we will include in the puskesmas' work plan." (R00PB1)
The interview results were in accordance with the hypertension screening guidelines, in which all screening activities had to be conducted based on hypertension screening guidelines, and one of the planning processes or the initial planning activities was HOA fund budgeting. ${ }^{4}$

From the interview results, the informant also stated that the guidelines were technical instructions or references prepared by experts, which were used as references by health workers. Hypertension screening was also a monthly routine activity in the hamlets of the local villages, in the form of blood pressure measurement and drug administration. This information signifies that the awareness of health care workers in charge in hypertension screening program has been adequate and the implementation of screening was based on the guideline from $\mathrm{MoH}$.

"... Screening guidelines are technical instructions or references compiled by cross-program experts of the Ministry of Health, which are used as references by health workers and program managers in developing programs for reducing hypertension risk factors, early detection of hypertension, and its prevention." (R00PTK1)
"... The activities carried out in the hamlets or the villages are blood pressure measurement and drug administration." (R00MP1)

The results were not in accordance with hypertension screening guidelines. In the guidelines, it is explained that hypertension control efforts are conducted based on cooperation from various parties, either government or community members. The government with various institutions under the government and people with various levels and various professions support each other for the success of the activity implementation, especially healthbased activities, as an effort to control NCDs to reduce the incidence of NCDs. ${ }^{4}$

\section{The availability of funds for hypertension screening activities}

In-depth interviews showed informants' knowledge of the availability of funds for hypertension screening activities. The informants (the head of the puskesmas and the program holder) generally reached a consensus that the main funding for this activity came from the local government budget through the Health Office.

Table 1. Characteristics of Informants

\begin{tabular}{|c|c|c|c|c|c|c|}
\hline Code & $\begin{array}{l}\text { Age } \\
\text { (years) }\end{array}$ & Sex & Occupation & Education & Position & $\begin{array}{l}\text { Length of } \\
\text { Employment }\end{array}$ \\
\hline R00PB1 & 45 & $\mathrm{~F}$ & Civil servant & $\mathrm{MD}^{*}$ & Head of PHC & 10 years \\
\hline R00PK1 & 34 & $\mathrm{~F}$ & Civil servant & $\mathrm{MD}$ & Head of PHC & 9 years \\
\hline R00PPB1 & 27 & $\mathrm{~F}$ & Employee & $\begin{array}{l}3 \text {-year Diploma in } \\
\text { Midwifery }\end{array}$ & Chairman of the NCD Program Holder & 5 years \\
\hline R00PPK1 & 34 & $\mathrm{~F}$ & Civil servant & $\begin{array}{l}3 \text {-year Diploma in } \\
\text { Nursing }\end{array}$ & Chairman of the NCD Program Holder & 9 years \\
\hline R00PTB1 & 27 & $\mathrm{~F}$ & Contract employee & $\begin{array}{l}\text { 3-year Diploma in } \\
\text { Midwifery }\end{array}$ & Hypertension screening officer & 5 years \\
\hline R00PTK1 & 32 & $\mathrm{~F}$ & Contract employee & Nurse & Hypertension screening officer & 3 years \\
\hline R00KB1 & 45 & $\mathrm{~F}$ & Entrepreneur & Senior high school & Hypertension screening implementation cadre & - \\
\hline R00KP1 & 46 & $\mathrm{~F}$ & $\begin{array}{l}\text { Private sector } \\
\text { worker }\end{array}$ & $\begin{array}{l}1 \text {-year Diploma in } \\
\text { Tourism }\end{array}$ & Hypertension screening implementation cadre & - \\
\hline R00MB1 & 51 & $\mathrm{~F}$ & Entrepreneur & Senior high school & $\begin{array}{l}\text { A person that had participated in hypertension } \\
\text { screening }\end{array}$ & - \\
\hline R00MP1 & 49 & M & Entrepreneur & Senior high school & $\begin{array}{l}\text { A person that had participated in hypertension } \\
\text { screening }\end{array}$ & - \\
\hline
\end{tabular}

${ }^{*} \mathrm{MD}=$ medical doctor 
"The funding is still from one source, namely the HOA fund for the posbindu." (R0OPB1)

Besides that, several informants also provided additional information regarding fund resources that could also be used for this activity implementation.
One of the informants stated that there was a convergence of hypertension screening activities with the program from the Healthcare and Social Security Agency (BPJS) called as Prolanis Program. Thus, the capitation funds from BPJS could be used for hypertension screening. Besides that, the informants also revealed the potency for funding cooperation advocacy from village funds and private sectors in public-private partnerships.

"the hypertension screening is also included in the Prolanis Thus, in the budgeting, we will include it in the work plan... Besides that, collaboration with the private sector is also good to support

\section{Table 2. Themes and Sub-themes}

\begin{tabular}{|c|c|c|}
\hline Themes & Sub-themes & Aspects \\
\hline \multirow[t]{4}{*}{$\begin{array}{l}\text { Predisposing } \\
\text { factors in the } \\
\text { implementation } \\
\text { of hypertension } \\
\text { screening guidelines }\end{array}$} & $\begin{array}{l}\text { Knowledge regarding the } \\
\text { implementation of hypertension } \\
\text { screening guideline among health care } \\
\text { staffs }\end{array}$ & $\begin{array}{l}\text { - } \quad \text { Stages of the hypertension screening guidelines implementation } \\
\text { - } \quad \text { Staff involved in the screening }\end{array}$ \\
\hline & Availability of funds & $\begin{array}{ll}\text { - } & \text { Source of fund } \\
\text { - } & \text { Identification of other potential funding }\end{array}$ \\
\hline & Planning and preparation & $\begin{array}{ll}\text { - } & \text { Arrangement of location, time of screening } \\
\text { - } & \text { Notification of community leader } \\
\text { - } & \text { Refresher training for cadres }\end{array}$ \\
\hline & $\begin{array}{l}\text { People's beliefs and attitude regarding } \\
\text { hypertension screening }\end{array}$ & $\begin{array}{l}\text { - The people's enthusiasm was very high } \\
\text { - Some community members were active, and some of them were not } \\
\text { active }\end{array}$ \\
\hline \multirow{2}{*}{$\begin{array}{l}\text { Driving factors in } \\
\text { the implementation } \\
\text { of hypertension } \\
\text { screening guidelines }\end{array}$} & The role of health workers & $\begin{array}{l}\text { - Creating a work planning team and discussing work mechanism } \\
\text { - Participating in all screening activities, from anamnesis to counseling } \\
\text { - } \quad \text { Providing places and locations and making announcements }\end{array}$ \\
\hline & The role of health cadres & $\begin{array}{l}\text { - Communicate with community leader and members } \\
\text { - Provide health education } \\
\text { - Prepare paperwork, data collection and reporting }\end{array}$ \\
\hline \multirow[t]{3}{*}{$\begin{array}{l}\text { Supporting factors in } \\
\text { the implementation } \\
\text { of hypertension } \\
\text { screening guidelines }\end{array}$} & Support from health workers & $\begin{array}{l}\text { - } \quad \text { The integrated team between all health workers } \\
\text { - } \quad \text { There was still lack of health workers } \\
\text { - } \quad \text { The health workers were friendly and supportive }\end{array}$ \\
\hline & Community support & $\begin{array}{l}\text { - } \quad \text { Constraints on the activity schedule } \\
\text { - } \quad \text { The community members were quite active }\end{array}$ \\
\hline & Facilities and infrastructure support & $\begin{array}{l}\text { - The need for medical equipment, such as sphygmomanometers, } \\
\text { stethoscope, measuring tape, weight scales, and height measuring } \\
\text { devices } \\
\text { - Examination tools from the local PHC }\end{array}$ \\
\hline \multirow[t]{2}{*}{$\begin{array}{l}\text { Inhibiting factors in } \\
\text { the implementation } \\
\text { of hypertension } \\
\text { screening guidelines }\end{array}$} & $\begin{array}{l}\text { Obstacles in the implementation of } \\
\text { hypertension screening }\end{array}$ & $\begin{array}{l}\text { - The lack of human resources/health workers } \\
\text { - The lack of community participation and awareness } \\
\text { - The lack of collaboration between all activities supporting the } \\
\text { hypertension screening }\end{array}$ \\
\hline & $\begin{array}{l}\text { Difficulties in achieving the } \\
\text { target of hypertension screening } \\
\text { implementation }\end{array}$ & $\begin{array}{l}\text { - Still far from target due to high productive age, busy working } \\
\text { - } \quad \text { Not achieved due to lack of health workers and lack of community } \\
\text { participation } \\
\text { - The screening activity had met the target }\end{array}$ \\
\hline $\begin{array}{l}\text { Monitoring and } \\
\text { Evaluation }\end{array}$ & $\begin{array}{l}\text { Monitoring and evaluation process of } \\
\text { hypertension screening activities }\end{array}$ & $\begin{array}{l}\text { - Coordination with the health office } \\
\text { - Collaboration between program holders and health workers involved in } \\
\text { the activity } \\
\text { - Monitoring the program coverage, the activity executors, and trained } \\
\text { cadres that were conducted after the activity ended }\end{array}$ \\
\hline
\end{tabular}


this screening ...”. (R00PB1)

"... We also advocate some funds that cannot be disbursed to the village because there is also a fund in the village ..." (ROOPK1)

The literature showed that fund availability was one of the important factors determining the success of hypertension screening activities, the coverage extent, and the benefits provided from these activities. A study in Tibet, China, reported that the lack of funds was one of the factors that caused the failure of the hypertension screening program coverage. ${ }^{12}$ Similar finding was also reported by a study in Indonesia. ${ }^{13}$ The funding management of hypertension screening activities involving the collaboration of funding sources from the government village funds, and the private sector was also in accordance with the guidelines concerning the management of hypertension screening program from the Ministry of Health. ${ }^{14}$

In-depth interviews also indicated that Puskesmas Kediri I tended to describe more conservative funding sources (i.e., from the Health Office with the possibility of funding from village funds), while Puskesmas Baturiti I seemed more innovative on this aspect by inclusion of alternative funding sources. Beside village funds, the informants from Puskesmas Baturiti I explained the possibility of funding from the BPJS budget and collaboration with the private sector. The interview results showed that Puskesmas Baturiti I, with better hypertension screening achievements, showed better initiative and innovation than Puskesmas Kediri I.

\section{Planning dan preparation hypertension screening activities}

According to the informants, the planning and preparation of hypertension screening activities began with identifying problems related to the implementation of hypertension screening activities based on previous activity reports. More appropriate implementation efforts could be made by reflecting from previous experience both positive and negative aspects. The flow of screening activities was carried out based on trends and a case overview in the previous year. The screening activities were prepared at the beginning of the year by the program manager. The flow of activities began with more complete preparation of all elements which included location, human resources, time, and sending notification to the village before the activity began.

"... We look at the data from the previous two years. We see what the trend is and how the case is increasing. We then make plans for the following year. For example, we make a plan for 2020. We can see the trend in 2018, and then we make a plan for 2019 and 2020." (R0OPK1)

The interview results showed that Puskesmas Kediri I prepared the hypertension screening activities based on the results of the previous activity plan. They also organized the activity flow by making an agreement on the activity schedule with the community, preparing the location to be used as a place of activity, and announcing the activity to the community through the hamlet head. It could be seen that Puskesmas Baturiti I planned the activity systematically and involved the community throughout the implementation of the hypertension screening activity flow. Thus, the implementation could run well.

According to the previous study, every screening result had to be recorded and became a good database if carried out in an integrated manner. This reporting system required good preparation so as not to burden cadres, and policyholders could use the results to formulate the next program or activity.

\section{People's attitudes and beliefs regarding hypertension screening}

According to the health officers, some people were active, and some were less active in participating in the hypertension screening. The people were positive about hypertension screening activities. However, people's attitudes were still also influenced by the perception that the screening activity was primarily a health check and treatment activity, not as a form of early detection of hypertension and proactive prevention, as mentioned above. People's attitudes in responding to this screening were not in accordance with the literature. Ideally, the people should be proactive in doing prevention, while people in this study considered screening as a curative activity. ${ }^{15}$

"... There were some people here who are actively participating in hypertension screening activities, but some are not active because most of them are busy working" (R0OPTK1)

In terms of belief, the public's desire and enthusiasm to participate in hypertension screening activities were very high. People believed that hypertension screening activities provided benefits, including obtaining health checks and medicines. People asserted that the benefit obtained from the screening was hypertensionrelated health information as an additional benefit from the activity.

“... Because my blood pressure was checked. I also get information about health and healthy lifestyle and medicines" (R00MP1)

"... I do intend to seek treatment. I want to check my health and blood pressure to know my health condition" (ROOMB1)

Previous research supported this finding. An important factor in measuring the success of hypertension screening was the community's readiness in implementing and utilizing hypertension screening activities, especially in receiving information provided by health workers.' Another study also reported that belief in the benefits of screening activities could increase participation and success in early detection and prevention programs. ${ }^{16}$

\section{Driving Factors in the Implementation} of Hypertension Screening Guidelines The driving factors in the implementation of hypertension screening guidelines could be seen from the internal aspects of the program, i.e., the human resources involved in the activities. The human resources involved in screening activities in the two PHCs that became the study sites were professional health workers and health cadres from the community. Indepth interviews found the perceptions of health workers and cadres regarding their respective roles. 


\section{The role of health workers in} hypertension screening activities

The driving factor affecting the implementation of hypertension screening guidelines was the role of health workers. Health workers involved in hypertension screening activity included several professions, i.e., doctors, nurses, analysts, and pharmacists. Besides that, the health workers' involvement was also seen from their functional role in which health workers in charge of the NCDs prevention program, health promotion, posbindu, and mobile puskesmas were involved in this activity.

"...It is an integrated team where all team members are interconnected. There are general practitioners, nurses, the program holders of posbindu, health promotion, and environmental health, analysts, and pharmacists in one team." (R00PB1)

Regarding the officer's role, there was a consensus that health workers played a role in anamnesis, examination, and health counseling. Health workers provided hypertension-related health services according to their respective knowledge and professions.

"The role of a hypertension screening officer is to participate in all hypertension screening activities, starting from initial anamnesis, assessment, and examination to post-examination counseling and evaluation." (R0OPTB1)

The role of professional health workers in hypertension screening has been previously known. A study in China reported the integration of hypertension identification service and hypertension case reporting in primary health services as an effort to prevent hypertension. ${ }^{17}$ In fact, there had been a study indicating that this role could be fulfilled by paramedics, such as nursing students. ${ }^{18}$ Health workers are expected to be aware of their responsibilities in examining and identifying the risk of the patients and providing information. ${ }^{19,20}$

According to the Indonesian Ministry of Health, early detection of hypertension through hypertension screening is conducted in several stages, i.e., indepth interview, blood pressure and pulse measurements, anthropometric measurements, and body mass index (BMI) calculation. After detecting hypertension and its risk factors as early as possible, trained cadres will perform counseling related to hypertension screening. ${ }^{4}$

\section{The role of health cadres in hypertension screening activities}

Health cadres also played an important role in hypertension screening. As a community-based activity, the health cadres acted as a bridge connecting health workers and health services with community components.

In-depth interviews with health cadres in the two PHCs showed a consensus regarding the cadres' role in hypertension screening activities. Health cadres had a role in the activities' technical preparation, from site preparation to administrative preparation. Besides that, health cadres were also given responsibility for recording and reporting the activities.

"My duties are to provide activity locations, prepare venues, announce the activity to the community through the local hamlet heads, and prepare activity report books." (R00KP1)

The program holders and health workers in each PHC also reported a consensus on the important role of cadres in maintaining and improving the quality and achievements of hypertension screening activities. Health cadres were known to have been involved since the activity planning. Besides that, training and refreshment for health cadres were conducted to maintain and improve their abilities in activity implementation.

"First of all, we gather cadres for refreshment. We discuss what activities we will do and determine the schedule." (R00PPB1)

Previous literature supported the important role of health cadres in NCDs prevention and control programs, including hypertension screening activities. Health cadres were considered to have the potential to fill the shortage of human resources for professional health workers. The roles that could be filled by health cadres were from communicating with the community to collecting data in recording and reporting, ${ }^{21}$ which is align with the cadres' roles found in our study.

The role of health cadres in the two PHCs in this study was also following the guidelines from the Ministry of Health. After the people went through examination by health workers, trained cadres would conduct counseling related to hypertension screening and management. ${ }^{4}$ The cadre's role has also been determined in the Minister of Health Regulation Number 8 Year 2019 concerning Community Empowerment in the Health Sector. Health cadres are able to act as initiators, counselors, registrars, and rapporteurs on health activities in the community.

In-depth interviews also showed differences in the management of health cadres as human resources between Puskesmas Kediri I and Puskesmas Baturiti I. Although there was a consensus on the health cadres' training, only an informant from Puskesmas Baturiti I mentioned a refreshment for cadres before each activity that indicated a continuous capacity-building effort.

\section{Supporting and Inhibiting Factors in the Implementation of Hypertension Screening Guidelines}

Supporting and inhibiting factors were factors outside the team and institution implementing the hypertension screening activities. In-depth interviews found that the two factors described by the informants could act as supporting or inhibiting factors. These two factors were the availability of facilities and infrastructure required for activities and participation from the community as the main beneficiaries of hypertension screening activities.

\section{The availability of facilities and infrastructure for hypertension screening activities}

The facilities and infrastructure needed to perform hypertension screening activities were quite simple. Interviews with the informant found a consensus that the tools used in the activities were those available at the PHC and could be taken for activities outside the PHC (portable), such 
as stethoscopes and sphygmomanometers. "... For facilities and infrastructure, we only need sphygmomanometers. So, the consumables used are not too many if only for checking hypertension ..." (R00PK1)

Other than health equipment from the PHC, the facility or infrastructure needed was the availability of locations for the activities. In this case, there was a consensus from the community members, as the main beneficiaries, that the currently available locations in the two study sites were sufficient for implementing the activities.

"The place and location here are excellent, Sir ... because the activities are carried out in the hamlet or the village ..." (R00MB1)

Availability of adequate equipment had been reported as an obstacle to hypertension-related services, including screening, in primary health facilities in Vietnam. ${ }^{22}$ Similarly, community-based hypertension screening and treatment activities in Ghana also encountered problems, one of which was the availability of facilities and infrastructure. ${ }^{23}$

The basic examinations expected to be performed at the PHCs included blood pressure, height, weight, waist circumference, and hip circumference measurements. These measurements required simple tools. However, the guidelines also stated that the PHCs should ideally be able to perform more comprehensive supporting examinations, including blood sugar levels, lipid profiles, kidney function, urinary albumin, electrocardiogram, and cardiac enzymes. ${ }^{4}$ The guidelines for managing the NCDs control program also included the need for simple laboratory tests in the screening implementation, such as examining blood sugar levels and lipid profiles. ${ }^{14}$ Not all of this infrastructure yet available at the PHCs, these should be considered in the future to improve NCDs control at the PHCs.

\section{Community participation in hypertension screening activities}

There was a consensus from the informants that active community participation was considered a supporting factor in the success of hypertension screening activities. However, there were differences in perceptions regarding the community participation levels found in each research location (PHC). The informant from Puskesmas Kediri I tended to think that community participation was low, while those from Puskesmas Baturiti I viewed that community participation was high and active.

"... Some people here are active, and some are not active in participating in hypertension screening activities..." (R00PTK1)

"... The people here are very active, which can be seen from the arrival of the people of each village when we do the hypertension screening..." (ROOPTB)

In-depth interviews also identified several factors that affected community participation, according to the informants. Busy at work and conflict of schedule between the implementation of hypertension screening activities and people's working hours were considered obstacles to community participation. Low awareness was also considered an obstacle to community participation.

"... The workers... if we perform the screening while they are at work, it is hard to match the schedule ..." (R00PK1) "... the people's awareness for screening is still quite low ..." (ROOPPB1)

The low community participation in NCDs screening activities, including hypertension, has been identified as one of the obstacles to the success of the program in Indonesia. Two studies evaluating participation in prolanis and posbindu reported that community participation in these two activities was still very low, reducing their effectiveness. ${ }^{6,24}$ These results were similar to the one reported by the informant at Puskesmas Kediri I.

The schedule was identified by the informant as one of the obstacles to community participation. One of the efforts to overcome this obstacle was to provide hypertension screening activities outside working hours, such as weekends or other holidays. However, this will be not suitable for the health workers who were on duty during normal working hours. A study in Ghana found that health workers thought the activities conducted outside of working hours should be balanced with appropriate compensation..$^{23}$ Other recommendation is to provide service at two times schemes, morning for elderly or non-working target and evening for younger groups.

Another factor identified by the informant was the low public awareness on the program. The literature showed that strengthening health promotion was one of the effective efforts to overcome this obstacle. One of the studies in Zimbabwe showed that health cadres could be empowered to encourage health promotion to increase community participation in hypertension prevention. ${ }^{25}$ It was also in line with the Minister of Health Regulation Number 8 of 2019 concerning Community Empowerment in the Health Sector, which mandated the role of health cadres in health promotion and education.

\section{Monitoring and Evaluation Process of Hypertension Screening Activities}

We found monitoring and evaluation of hypertension screening activities involved several parties, including the coordinator, the person in charge, and the implementing officer. The monitoring was performed by observing the conformity of implementation with guidelines, plans, and service coverage achievements. The monitoring results then became evaluation materials and input in planning the next activity, which became a predisposing factor for the next activity.

"The program holders monitor directly the activities conducted in the community. Because this is a teamwork, all parties remind each other of the implementation standards. Thus, monitoring is performed directly in the field to observe whether the blood pressure monitoring method is correct or whether the activities have been conducted..." (R0OPK1)

The informants did not mention in detail the performance indicators that became the materials for monitoring and evaluation. According to the guidelines of hypertension control and management of NCDs control programs, the main 
indicator for evaluating hypertension screening activities was the proportion of patients with hypertension aged 15 years and above that received regular treatment. There were several intermediate indicators to obtain the final indicator, one of which was the coverage of the population aged 15 years and above who knew their blood pressure., ${ }^{4,14}$ This indicator was comparable to the monitoring and evaluation scheme established by several other countries whom were the Pan-American Health Organization (PAHO) members. ${ }^{2}{ }^{6}$

There was a difference in the coverage achievement of screening activities between Puskesmas Kediri I and Puskesmas Baturiti I which was achieved at Puskesmas Baturiti I and was not at Puskesmas Kediri I. According to the guidelines of hypertension control and management of NCDs control programs from the Ministry of Health, the target coverage of hypertension screening activities is determined by the Health Office in each district/city. This target is determined based on data regarding the achievements of the activities that have been conducted. ${ }^{4,14}$ The target determined for each PHC could affect the success of the achievement.

"... The coverage is still far from the target because the target for hypertension treatment is the case found in productive age. The number of hypertension cases in this age group is high. Therefore, the achievement data must look small." (R00PK1)

"... The achievement has reached the target. Thus, for the next implementation, we will only follow up on how to prevent and treat complications that occur." (R0OPB1)

Apart from the possible differences in targets, we found differences in of both PHCs which was reflected on the factors described on the previous themes. Puskesmas Baturiti I showed initiative to seek other funding sources, better involvement of the community which influence better community participation and also provision of refresher training for cadres.

Limitation of this study was the difficulty of conducting a structured evaluation due to current conditions in which there were increasing cases of
COVID-19, and thereby we should limit regular or repeated meetings with PHCs' officers and the people. Puskesmas' policy regarding restrictions on activities outside the building including hypertension screening has made direct observation of the implementation of hypertension screening guideline was not able to be conducted.

\section{CONCLUSION}

From this study we found predisposing factors to the implementation of hypertension screening guideline was health workers' knowledge about the implementation of hypertension screening guidelines, availability of budget including innovation to include more funding sources, and peoples' belief and attitude to the screening programs. The role of health workers and cadres are essential to achieve effective screening program, and refresher training to cadre is recommended prior to the implementation. Barriers to the implementation was wide coverage area, relatively low community participation which include productive age groups who are still actively working, and lack of resources.

The recommendation given to the PHCs related to the quality improvement of hypertension screening services is to deliver the screening in two different time schemes, morning for elderly people and afternoon for younger age groups. The number of health workers involved in each activity should be increased, transportation should be covered and inclusion of other funds such as from BPJS or other funding sources should be considered.

\section{ACKNOWLEDGMENTS}

The authors would like to thank the Tabanan District Health Office that had participated in this research, the Investment and One-Stop Service Office of Denpasar City, the National and Political Unity Agency of Tabanan District, Udayana University, and all parties that had contributed to this study.

\section{AUTHORS' CONTRIBUTIONS}

AR developed the study design, collected, and analyzed the data, and made the draft of the manuscript. DD and LA developed the study concepts and design, assisted in data analysis, provided suggestions, and input to the manuscript.

\section{CONFLICT OF INTEREST}

There was no conflict of interest declared in this study

\section{FUNDING}

This study was self-funded by the research team.

\section{REFERENCES}

1. The Ministry of Health of The Republic of Indonesia. Hasil Utama Riset Kesehatan Dasar 2018 [The main result of the 2018 Indonesia Basic Health Research]. Jakarta, 2018.

2. Noviyanti F, Decroli E, Sastri S. Perbedaan kadar LDL-kolesterol pada pasien diabetes melitus tipe 2 dengan dan tanpa hipertensi di RS Dr. M. Djamil Padang tahun 2011 [Differences in LDL-cholesterol levels in type 2 diabetes mellitus patients with and without hypertension at Dr. M. Djamil Padang 2011]. Jurnal Kesehatan Andalas. 2015; 4(2): 545-550.

3. Bali Provincial Health Office. Profil Kesehatan Provinsi Bali 2017 [The 2017 Bali Province Health Profile]. Denpasar, 2017.

4. The Ministry of Health of The Republic of Indonesia. Pedoman pengendalian hipertensi [Guidelines for the management of hypertension]. Jakarta, 2015.

5. Lawrence WG. Modifying and developing health behavior. Annual Review of Public Health. 1984; 5(1): 215-236.

6. Latifah I, Maryati H. Analisis pelaksanaan Program Pengelolaan Penyakit Kronis (Prolanis) BPJS Kesehatan pada pasien hipertensi di UPTD Puskesmas Tegal Gundil Kota Bogor [Analysis of the implementation of the BPJS Health Office Chronic Disease Management Program (Prolanis) for hypertension patients in Tegal Gundil Health Center, Bogor City]. Hear J Kesehat Masy. 2018; 6(2).

7. Sofiatin Y, Roesli RM. Kesiapan masyarakat dalam melaksanakan dan memanfaatkan Posyandu Penyakit Tidak Menular di Desa Cilayung dan Cipacing, Kecamatan Jatinangor [Community readiness in implementing and utilizing Non-communicable Disease Posyandu in Cilayung and Cipacing Village, Jatinangor Sub-district]. Glob Med Heal Commun. 2017; 5(2): 123.

8. Bintang S. Pelaksanaan program Pos Pembinaan Terpadu Penyakit Tidak Menular (Posbindu PTM ) pada penderita hipertensi di Puskesmas Padang Bulan tahun 2016 (Skripsi) [The implementation of non-communicable disease Posbindu for hypertension patients in Puskesmas Padang Bulan on 2016 (Undergraduate thesis)]. Universitas Sumatera Utara. Sumatera Utara; 2017. 
9. Creswell JW. Research design: qualitative, quantitative and mixed methods approaches. Sage Publ London. 2003.

10. Budiyanto E. Sistem informasi manajemen sumber daya manusia [Human resource management information system]. Graha Ilmu. 2013.

11. Moleong. Metodologi penelitian kualitatif [Qualitative reseach methodology]. Bandung: PT Remaja Rosdakarya. 2000.

12. Song C, Chongsuvivatwong V, Wangdui S, Mima D, Zhuoma C, Ji D, et al. Coverage and effectiveness of hypertension screening in different altitudes of Tibet autonomous region. BMC Public Health. 2021; 21(1): 1-10.

13. Fitriah N, Satya R, Kurniawan F, Santi BT. Pelatihan kader anti hipertensi di RW 15, Kelurahan Penjaringan, Jakarta Utara [Antihypertension cadre training at RW 15, Penjaringan Village, North Jakarta]. J Pengabdi pada Masy. 2021; 6(1): 274-82.

14. The Ministry of Health of The Republic of Indonesia. Manajemen program pencegahan dan pengendalian hipertensi dan perhitungan pencapaian SPM hipertensi [Management of hypertension prevention and control programs and calculation of hypertension SPM achievement]. Jakarta; 2018.

15. Lingam S, Rani PK, Sheeladevi S, Kotapati V, Das T. Knowledge, attitude and practices on diabetes, hypertension and diabetic retinopathy and the factors that motivate screening for diabetes and diabetic retinopathy in a pyramidal model of eye health care. Rural Remote Health. 2018; 18(1).

16. Neelakandan BV, Gopalakrishnan S, Ramachandran H, R A, Gopichandran V. Health beliefs regarding uptake of hypertension screening in an urban setting: a population segmentation strategy. Int $J$ Med Public Heal. 2018; 8(1): 11-7.

17. Feng YJ, Wang HC, Li YC, Zhao WH. Hypertension screening and follow-up management by primary health care system among chinese population aged 35 years and above. Biomed Environ Sci [Internet]. 2015; 28(5): 330-40.

18. Abdelsatir S, Al-Sofi A, Elamin S, Abu-Aisha $\mathrm{H}$. The potential role of nursing students in the implementation of community-based hypertension screening programs in Sudan. Arab J Nephrol Transplant. 2013; 6(1): 51-4.

19. Wassenberg MWM, Willemsen JM, Gaillard CA, Braam B. Hypertension management in primary care: standard care and attitude towards a disease management model. Neth $J$ Med. 2004; 62(10): 364-74.

20. Elizabeth C. Knowledge, Attitude and Practices (KAP) of healthcare workers in the Free State, South Africa regarding type 2 diabetes mellitus (Thesis). University of the Free State; 2016.

21. Jarvis JD, Kataria I, Murgor M, Mbau L. Community health workers: an underappreciated asset to tackle NCD. Glob Heart [Internet]. 2016; 11(4): 455-7.
22. Meiqari L, Nguyen TPL, Essink D, Zweekhorst $\mathrm{M}$, Wright P, Scheele F. Access to hypertension care and services in primary health-care settings in Vietnam: a systematic narrative review of existing literature. Glob Health Action [Internet]. 2019; 12(1).

23. Adler AJ, Laar AK, Kotoh AM, LegidoQuigley H, Perel P, Lamptey P, et al. Barriers and facilitators to the implementation of a community-based hypertension improvement project in Ghana: a qualitative study of ComHIP. BMC Health Serv Res. 2020; 20(1): 1-13.

24. Sujarwoto S, Maharani A. Participation in community-based health care interventions (CBHIs) and its association with hypertension awareness, control and treatment in Indonesia. PLoS One [Internet]. 2020; 15 (12 December): $1-18$.

25. Chimberengwa PT, Naidoo M. A description of community-based participatory research of hypertension awareness, prevention and treatment in a district of Matabeleland South Province, Zimbabwe. African J Prim Heal Care Fam Med. 2019; 11(1): 1-9.

26. Pan American Health Organization. Monitoring and evaluation framework for Hypertension Control Programs. Washington, D.C., 2018.

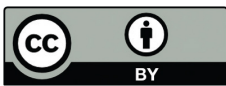

This work is licensed under a Creative Commons Attribution 